\title{
R. DARREN GOBERT \\ The Mind-Body Stage: Passion and Interaction in the Cartesian Theater.
}

Stanford: Stanford UP, 2013. 264 pp. 18 illustrations.

BRAD KRUMHOLZ

In The Mind-Body Stage: Passion and Interaction in the Cartesian Theater, R. Darren Gobert sets his sights on accomplishing two simultaneous tasks: to demonstrate the influence of René Descartes on theatre history and to rescue the philosopher from the persistent and pernicious tradition of "Cartesianism," which deforms and oversimplifies the complex and nuanced notions of Descartes to such an extent that our common sense of his philosophy has come to be more Cartesianist than Cartesian. On both counts, Gobert succeeds.

The first of the book's four chapters presents a little-known side of the great philosopher as librettist. Before getting to the real meat of his study - the remaining three sections, showing the influence of Descartes on playwriting, acting, and theatrical space-Gobert takes a moment to engage in a close reading of The Birth of Peace, an opera ostensibly penned by Descartes, which premiered in December of 1649 , the very same year and month as the philosopher's final treatise, The Passions of the Soul. This clever entrée allows the reader to take quite seriously the claim that Descartes had a very direct influence on the theatre of his own time, so much so that he participated in its creation on at least this one occasion. Also significant in this introductory section is the elucidation of the important and dynamic correspondence between Descartes and Princess Elisabeth of Bohemia, who was pivotal in the development of many of the philosopher's later ideas concerning mind-body unity.

As we move into the next section, Gobert's thesis really takes hold: he demonstrates with great flair and precision a largely overlooked aspect of theatre history, namely the interaction (as the book's subtitle would have it) of the newly-articulated Cartesian subject (and subjectivity) and the transformation of Neoclassical theatrical modes by prominent writers such as Corneille and Dryden. Gobert deftly makes a case for a number of compelling historical links in his book, and some of the most provocative appear in this section. For example, he draws a temporal connection between the publication of Descartes's Discourse on Method (1637) and the infamous controversy surrounding Corneille's El Cid (1637), and in so doing is able to embark upon a compelling account of Corneille's shift in dramatic ideals from Pity and Fear to that of Wonder (or Admiration); he also provides the reader with the Cartesian description of this very same passion. To this end Gobert provides a close reading of Corneille's later work, Nicomède (I65I), as an example par excellence of the Cartesian doctrine, mainly as it appears in The Passions of the Soul (I649). Nicomède, the hero, who, against the traditional Neoclassical Aristotelian constraints of tragedy, is introspective, virtuous, rational, and emotionally generous, embodies the newly conceived Cartesian subject. Of course, it would be a mistake to claim simply that Corneille was writing under the influence of Descartes. Gobert is careful not to make this assertion, and he understands that Corneille's anti-Aristotelian approach to Neoclassical ideals in theatre-making are properly to be seen as occurring contemporaneously with Descartes's anti-Aristotelian (anti-Scholastic) thinking. The influence is not unidirectional. 
It does appear, however, that the influence of Descartes on others was, in fact, more of a one-way affair. Gobert draws another fascinating association between the restoration of Princess Elisabeth's cousin, Charles II, to the English throne and the influence of French theatre not only on the English stage (which is commonly acknowledged), but also on English dramatic theory itself, namely as evidenced by Dryden's Corneille-inspired Of Dramatick Poesie, an Essay (1665). This philosophical closet drama stresses the centrality of Cornelian Wonder (Admiration) over the traditional Pity and Fear of Aristotle, thus planting the new Cartesian philosophy firmly in English theatrical soil.

In the next section, Gobert turns to the less direct, but still operative, Cartesian influence on innovations in acting style. Here, Gobert is at his best, combining his facility with close readings of text and rigorous analyses of material history to shed light upon the "quarrel" surrounding Molière's School for Wives. Focusing primarily on the tail end of this yearlong firestorm, Gobert takes the reader through Molière's The Versailles Impromptu (I663), painting a minutely detailed picture of his newly evolving acting style, the jeu naturel. Before getting to this point, however, the author traces the direct line between Descartes and innovations in aesthetic theory of the age in general, starting with Charles Le Brun and his highly influential manual for emotional representation in the visual arts, the Conference on General and Particular Expression (1668). Having established this connection, it is possible to follow the lines of influence to Molière and beyond. The most important point made in this part of the study is that the very concept of the actor's interiority, so central to modern acting as we have come to know it, would not be possible without the seed of Descartes's newly-fashioned subjectivity, the "I" who is able to reflect upon his own being. Furthermore, Gobert is sure to point out that the interaction between the psychology of the actor, the physical body, and his emotions develops entirely in accordance with Cartesian principles of mind-body unity and the passions.

It is important to make clear one of Gobert's main complaints, echoed repeatedly in this book, concerning the unity of the body and mind, especially as it appears in Descartes's later works, most notably The Passions. Although Descartes establishes the subjective "I" in his earliest writing, it is not until a bit later that he tackles mind-body unity. We can see already in the Sixth of his Meditations that he is making a clear case for unity; he touches upon the subject somewhat in his Replies to the Objections to the Meditations, and perhaps more importantly, in his letters to Princess Elisabeth. By the time Descartes writes The Passions, however, he sees the relationship between the mind and the body as unified, as coexistent and in a relationship of mutual (co)dependency. "Cartesianism," though, takes this complex and nuanced set of ideas and reduces it to a simplistic dualism, and while it is true that Descartes separates mind and body as discrete substances in his philosophy, he also understands that, in real life, we cannot have one without the other. This can be seen most starkly (and touchingly) in his letters to Princess Elisabeth, especially on the subject of her health and happiness.

After looking at the work of the actor, Gobert extends his fascinating study to the realm of theatrical space, especially the ways in which the new theatres of the period configured the experience of the audience/actor/play relationship in ways entirely under the influence of both Descartes and Cartesianism. Once again, the analysis is based in a close reading, this time of Racine's Phèdre over the course of three productions. The first of these 
is staged in the old, tennis-court style space of the Hôtel de Bourgogne, a theatre that figures prominently in Gobert's overall excavation of Cartesian theatrical influence (including the substance of the Bourguignons' antagonistic relationship to Molière, delightfully detailed in the previous section of the book). In the move from the play's premiere in this venue to its inaugural presentation at the Comédie-Française newly designed by François d'Orbay, we follow the shift typical of theatre in France at this time. From buildings in which audience and actors shared the same space (i.e. interacted), late seventeenth-century theatre gradually came to divide the spectator from the play, very much along the lines of strict Cartesianist mind-body separation. Again, Gobert does not claim that Descartes engineered any of this; rather, the spirit of the age, with Descartes's philosophical and mathematical influence, was moving inexorably toward such binary formations. While it is true that the reflective subject springs from the philosophy of Descartes, it is also true that the overdevelopment of this subject, into a mind thoroughly disconnected from its body, is a fundamentally anti-Cartesian proposal.

As it turns out, what Gobert is really charting in his book is a substantive shift in theatrical representation, and at the root of this shift-which was to influence all subsequent theatre in the so-called "Western" world-he locates Descartes. It is a bold and sweeping claim, but his research is sound and his reading of the philosopher's various texts is solid. If there is a fault to Gobert's project, it is to be found in his frequent and emphatic proclamations pointing toward the strength of his claims about Descartes's influence. Such reminders are unnecessary in such a comprehensive and well-researched study; they only serve to diminish the rightful impact of this otherwise impressive work. Truly, one gets the sense in reading Gobert's book that he has completely exhausted the archive, and while a full one-third of the book is taken up by endnotes, the reader feels not exhausted by the author's thoroughness, but impassioned by it.

Book Editor's Note: R. Darren Gobert's The Mind-Body Stage is the 2013 recipient of the Canadian Association of Theatre Research's Ann Saddlemyer Award for best book in English or French.

\section{SYLVAIN SCHRYBURT}

\section{De l'acteur vedette au théâtre de festival. Histoire des pratiques scéniques montréalaises (1940-1980).}

Montréal : Les Presses de l'Université de Montréal, 2011. 395 pp.

\section{LOUISE LADOUCEUR}

Cette étude suit l'évolution du théâtre d'expression française à Montréal sur quatre décennies pour y mettre en relief les différents régimes qui ont marqué la pratique théâtrale au cours de ces années. Un des mérites de l'ouvrage est de dégager non seulement ce qui appartient en propre à chaque régime, mais les facteurs contribuant au changement de régime et la façon dont chacun s'articule au précédent pour ensuite modifier l'horizon d'attente du milieu théâ- 